\title{
Power generation of the midfoot in children wearing sports shoes
}

\author{
Caleb Wegener ${ }^{1 *}$, Andrew Greene ${ }^{1,2}$, Joshua Burns $^{3}$, Benedicte Vanwanseele ${ }^{1,4}$, Adrienne E Hunt $^{1}$, \\ Richard M Smith ${ }^{1}$ \\ From Australasian Podiatry Council Conference 2013 \\ Sydney, Australia. 2-5 June 2013
}

\section{Background}

During propulsion of walking the midfoot generates 35 to $48 \%$ of the peak power from the foot and ankle. This study aimed to investigate the effect of children's sports shoes on midfoot kinetics during propulsion of walking and running.

\section{Methods}

Twenty children performed five walking and running trials at a self-selected velocity while barefoot and wearing a common sports shoe. Footwear testing order was randomised. A 14 camera motion analysis system was used to calculate retro-reflective marker trajectories at $200 \mathrm{~Hz}$. Markers were attached to the leg and to the foot through holes in the shoe to measure three-dimensional motion of the midfoot and ankle. Ground reaction force data were recorded at $1,000 \mathrm{~Hz}$. Data were normalised to the stance phase and analysed from $60 \%$ to $100 \%$.

\section{Results}

Peak midfoot power generation during walking reduced from $1.67 \mathrm{~W} / \mathrm{kg}$ (SD 0.59) barefoot to $0.50 \mathrm{~W} / \mathrm{kg}$ (SD $0.26)$ in the sports shoe $(P<0.0005)$. Peak ankle power generation during walking was increased from $1.49 \mathrm{~W} / \mathrm{kg}$ (SD 0.42) barefoot to $1.89 \mathrm{~W} / \mathrm{kg}$ (SD 0.44) in the sports shoe $(P<0.0005)$. Peak midfoot power generation during running was significantly reduced from $3.92 \mathrm{~W} / \mathrm{kg}$ (SD 1.33 ) barefoot to $1.56 \mathrm{~W} / \mathrm{kg}$ (SD 0.76) in the sports shoe $(P<0.0005)$. Peak ankle power generation during running increased from $4.77 \mathrm{~W} / \mathrm{kg}$ (SD 1.02) barefoot to $6.03 \mathrm{~W} / \mathrm{kg}$ (SD 1.14) in the sports shoe $(P<0.0005)$.

\footnotetext{
* Correspondence: caleb.wegener@sydney.edu.au

'Discipline of Exercise and Sport Science, Faculty of Health Sciences, The University of Sydney, NSW, 1825, Australia
}

Full list of author information is available at the end of the article

\section{Conclusion}

Children compensate for a reduction in midfoot power generation in sports shoes by increasing ankle power generation with potential implications for overuse of the Achilles tendon and triceps surae muscle complex.

\begin{abstract}
Author details
${ }^{1}$ Discipline of Exercise and Sport Science, Faculty of Health Sciences, The University of Sydney, NSW, 1825, Australia. ${ }^{2}$ Faculty of Health, Social Care \& Education, Anglia Ruskin University, Chelmsford, CM1 1SQ, England, UK. ${ }^{3}$ The University of Sydney and The Children's Hospital at Westmead, Sydney, Australia. ${ }^{4}$ Department of Kinesiology, KULeuven, Leuven, Belgium/Chair Health Innovation and Technology, Fontys University of Applied Sciences, Eindhoven, the Netherlands.
\end{abstract}

Published: 31 May 2013

doi:10.1186/1757-1146-6-S1-O35

Cite this article as: Wegener et al.: Power generation of the midfoot in children wearing sports shoes. Journal of Foot and Ankle Research 2013 6(Suppl 1):035.

Submit your next manuscript to BioMed Central and take full advantage of:

- Convenient online submission

- Thorough peer review

- No space constraints or color figure charges

- Immediate publication on acceptance

- Inclusion in PubMed, CAS, Scopus and Google Scholar

- Research which is freely available for redistribution

Submit your manuscript at www.biomedcentral.com/submit 